\title{
KEMAMPUAN ANTI BAKTERI EKSTRAK DAUN KERSEN TERHADAP Salmonella typhi SECARA IN VITRO MELALUI MODIFIED FREE INQUIRY
}

\author{
Lukas Seran*1, Rikardus Herak², Sardina Ndukang ${ }^{3}$, Eduardus Johanes Eduk 4 , \\ Aloysius Djalo 5 \\ 1,2,3,4,5 Program Studi Pendidikan Biologi, FKIP, Universitas Katolik Widya Mandira, \\ Kupang, Indonesia \\ e-mail: ${ }^{1}$ lukasseran08@gmail.com, ${ }^{2}$ herakricky@gmail.com, \\ ${ }^{3}$ sardinandukang59@gmail.com, ${ }^{4}$ eduarduseduk@gmail.com, \\ 5aloysiusdjalo31@gmail.com
}

\begin{abstract}
ABSTRAK
Masalah yang dihadapi manusia mengkonsumsi obat sintetik yang berdampak buruk terhadap kesehatan tubuh. Sebagai solusi manusia mencoba kembali menggunakan bahan alam untuk menyembuhkan berbagai penyakit terutama penyakit menular yang di deritanya tanpa berdasarkan pada hasil kaian ilmiah dari bahan alam tersebut baik mengenai khasiat maupun efek sampingnya Daun Kersen merupakan bahan alam yang biasa di konsumsi untuk mengobati penyakit tifus. Tetapi apakah benar berkhasiat belum diketahui. Oleh karena itu penelitian ini bertujuan untuk membuktikan ada tidaknya kemampuan ekstrak daun kersen sebagai anti bakteri terhadap Salmonella typhi. Metode yang digunakan dalam penelitian ini adalah eksperimen laboratorium in vitro melalui pendekatan difusi dengan mengukur luas zona hambat. Hail yang diperoleh yaitu ekstrak daun kersen terbukti berkemampuan sebagai anti bakteri terhadap Salmonella typhi. Yang dibuktikan dengan data hasil ANAVA satu arah $\mathrm{F}$ hitung $=8,00>\mathrm{F}$ Tabel $=7,59$, sedangkan hasil uji lanjutan BNT menunjukkan bahwa antar perlakuan dengan konsentrasi berbeda memiliki kemampuan anti bakteri yang berbedabeda dan perlakuan yang paling besar kemampuan anti bakterinya terhadap Salmonella typhi yaitu $100 \%$. Hal baru yang ada pada penelitian ini yaitu penelitian dengan menggunakan metode saintifik termodifikasi dalam pembelajaran dan pengujian kemampuan anti bakteri ekstrak daun kersen terhadap Salmonella typhi belum pernah dilakukan.
\end{abstract}

Kata Kunci : Anti bakteri, Kersen, Inkuari bebas termodifikasi

\section{ABSTRACT}

Problems faced by humans taking synthetic drugs have a negative impact on body health. As a solution, humans try to re-use natural ingredients to cure various diseases, especially infectious diseases that they suffer without being based on the results of scientific studies of these natural ingredients, both regarding their properties and side effects. Kersen leaves are natural ingredients commonly consumed to treat typhus. But whether it really works is not known. Therefore this study aims to prove whether or not the ability of cherry leaf extract as anti-bacterial against Salmonella typhi. The method used in this research is an in vitro 
laboratory experiment through a diffusion approach by measuring the area of the inhibition zone. Hail obtained, namely cherry leaf extract proven to have anti-bacterial properties against Salmonella typhi. As evidenced by the one-way ANOVA result data F count $=8.00>$ $F$ table $=7.59$, while the LSD advanced test results showed that between treatments with different concentrations had different anti-bacterial abilities and the treatment had the greatest anti-bacterial ability. against Salmonella typhi which is $100 \%$. The new thing in this research is research using modified scientific methods in learning and testing the antibacterial ability of cherry leaf extract against Salmonella typhi has never been done.

Keyword: Anti-bacterial, Kersen, Modified free inquiry

\section{PENDAHULUAN}

Kesehatan merupakan hal yang sangat penting dan tidak ternilai bagi setiap individu. Semua orang memiliki keinginan untuk mendapatkan kehidupan yang sehat. Kesehatan sebagai suatu syarat untuk mewujudkan perkembangan jasmani, rohani dan sosial yang serasi. Undang-undang RI No.36 tahun 2009 tentang kesehatan, mengatakan bahwa kesehatan adalah keadaan sehat baik secara fisik, mental, spritual maupun sosial yang memungkinkan setiap orang untuk hidup produktif secara sosial dan ekonomi.

Salah satu keadaan tidak normal bahkan dapat menimbulkan kematian pada manusia yaitu adanya serangan penyakit, termasuk penyakit menular. Masalah kesehatan merupakan masalah kompleks yang merupakan resultan dari berbagai masalah lingkungan yang bersifat alamiah maupun masalah buatan manusia. Cara hidup dan gaya hidup manusia merupakan fenomena yang dapat dikaitkan dengan munculnya berbagai macam penyakit (Seran, L dan Herak, R, 2020). Salah satu penyakit menular yang sangat berbahaya bagi manusia yaitu penyakit tifus yang disebabkan oleh infeksi Salmonella typhi. Angka keadian dari penyakit ini akan semakin meningkat bila manusia hidup dalam lingkungan yang kotor, kumuh dengan cara meniivasi jaringan tubuh kemudian diikuti dengan penggandaan diri lalu melapaskan racun kedalam tubuh hospes (Soedarto, 2015).
Biasanya untuk mengatasi penyakit tifus tersebut penderita mengkonsumsi obat sintetik yang pada bagian lain dapat menyembuhkan penyakit tifus tetapi ada efek ikutannya yang sangat serius baik bagi pasien maupun bagi bakteri penyebab penyakit. Bagi Pasien obat sintetik memberi dampak terhadap tubuh berupa terjadi penumpukan residu bahan-bahan kimia obat yang kemudian merancuni sel-sel tubuh. Bagi bakteri penyebab penyakit, obat sintetik bila dikonsumsi secara tidak teratur dan berlebihan akan menimbulkan efek resistensi sehingga bakteri tersebut menjadi sulit untuk dikendalikan (Soeryoko, 2013).

Di Nusa Tenggara Timur (NTT) akhirakhir ini masayarakat menyadari akan bahaya obat sintetik sebagaimana dikemukakan di atas. Hal ini menumbuhkan kesadaran baru untuk mengkonsumsi obat-obatan tradisional dalam rangka menyembuhkan penyakit yang dialami..

Harapan untuk menjadikan bahan alam sebagai sumber daya obat altenatif itu menjadi beralasan sebagai mana tren konsumsi obat tradisional yang semakain meningkat. Hal ini menurut Sukandar (2006), faktor pendorong terjadinya peningkatan penggunaan obat herbal di negara Indonesia adalah karena usia harapan hidup yang lebih panjang pada saat prevalensi penyakit kronik, adanya kegagalan penggunaan obat medis, semakin luas akses informasi mengenai obat herbal diseluruh dunia serta karena terdapat efek kelebihan dari pengobatan herbal. 
World Health Organization (WHO) atau Badan Kesehatan Dunia menyebutkan bahwa hingga $65 \%$ dari penduduk negara maju menggunakan pengobatan tradisional dan obat-obat dari bahan alami (Kemenkes RI, 2007). Tren di atas terjadi karena adanya pemahaman tentang keunggulan dari obat herbal yaitu dapat menyembuhkan penyakit dan rendah efek samping, walaupun dalam waktu yang agak lebih lama dibanding obatobatan sintetik modern.

Masalah yang dihadapi ialah kepastian mengenai khasiat dan efek samping yang akurat dari bahan-bahan alam potensial obat termasuk tumbuhan kersen yang dikonsumsi oleh masayarakat di desa Penfui Timur Kabupaten Kupang belum diketahui secara ilmiah.

Berhadapan dengan masalah faktual di atas maka ikhtiar untuk mencari alternatif lain yang lebih nyaman terhadap pasien dan dapat meminimalisir timbulnya resistensi pada mikroba penyebab yaitu dengan melakukan penelitian terhadap bahan-bahan alam potensial sebagai obat yang digunakan secara tradisional oleh kelompok-kelompok masyarakat tersebut di atas.

Berdasarkan hasil telaahan referensi yang ada hasil penelitian mengenai khasiat daun kersen untuk menyembuhkan penyakit menular terutama terhadap penyakit tifus belum tersedia. Agar kelompok masyarakat pengguna tidak percaya pada ilusi yang salah atas khasiat daun kersen maka penelitian dalam rangka pembuktian kemampuan anti bakteri dari daun kersen terhadap Salmonella typhi (penyebab penyakit tifus) sangat penting untuk dilakukan.

\section{METODE}

Penelitian ini merupakan eksperimen sungguhan (thrue eksperiment) yang dilaksanakan di Laboratorium Mikrobiologi Universitas Katolik Widya Mandira dengan menggunakan The Post Test Only Control Group Design, 4 perlakuan diulang 3 kali
Program Studi Pendidikan Biologi Universitas Katolik Widya Mandira, merupakan lembaga penghasil tenaga pendidik yang harus memiliki empat Kompetensi sebagai mana yang diamatkan di dalam Undang-Undang Sistem Pendidikan Nasional No 32 tahun 2005 yaitu Kompetensi Pedagogik, Kompetensi profesional (keilmuan), kompetensi kepribadian dan Kompetensi social.Untuk mewujudkan amanat Undang-Undang tersebut, maka dilakukanlah penelitian dengan menggunakan dua pendekatan yaitu pendekatan eksperimentasi untuk membuktikan pengaruh variabel bebas terhadap variabel terikat yang merupakan cara membentuk kompetensi keilmuan dan kepribadian; pendekatan pembelajaran dengan menggunakan model inquiry bebas termodifikasi untuk membentuk kompetensi Pedagogik.

Peneliti berkeyakinan bahwa variabel bebas (ekstrak daun kersen) akan terbukti berkemampuan sebagai anti bakteri Salmonela typhi karena ekstrak tersebut mengandung senyawa-senyawa aktif yang dapat berinteraksi secara kimiawi dengan bahan penyusun tubuh sel bakteri Salmonella typhi sehingga menyebabkan sel bakteri Salmonella typhi terhambat pertumbuhannya bahkan membunuh sel bakteri Salmonella typhi tersebut. Selanjutnya dengan dilaksanakannya penelitian dalam pembelajaran menggunakan model inquiry bebas termodifikasi maka para subjek peneltian akan terbentuk keterampilan proses dalam pembelajaran saintifik yang digunakan.

dan1 kontrol. Sesuai dengan rancangan yang dugunakan maka penelitian ini hanya mengukur data setelah diberi perlakuan dan dari setiap replikasi. Rincian dari ke empat perlakukan yaitu perlakuan 1 menggunakan konsentrasi ekstrak 25\%, perlakuan ke 2 menggunakan konsentrasi ekstrak 50\%, 
Perlakuan ke 3 menggunakan konsentrasi ekstrak 75\% dan perlakukan ke 4 menggunakan konsentrasi ekstrak 100\%. Sedangkan kontrol menggunakan aquades steril. Total unit perlakuan dalam penelitian ini yaitu 12 unit perlakuan yang didapat dari jumlah perlakuan dikalikan dengan jumlah ulangan.

Penelitian dilaksanakan dalam pembelajaran dengan menerapkan salah satu metode pembelaaran saintifik yaitu inquairy bebas. Karena penelitian tidak menggunakan tahapan-tahapan inquairy bebas sebagaimana adanya (tidak akomodatif) maka tahapan inquairy dimodifikasi dengan mengembangkan tahapan inquairy tersebut yang akomodatif sebagai mana yang diuraikan pada bagian berikut ini.

1)Tahap persiapan pembelajaran: Penyusunan rubrik penilaian keterampilan proses mahasiswa dan Orentasi pemahaman mahasiswa terhadap rublik.

2) Tahap persiapan eksperimentasi meliputi: mempersiapkan dan mensterilisasikan alat dan bahan, mengadakan dan membuat sampel ekstrak ke dalam konsentrasi perlakuan yaitu $25 \%, 50 \%, 75 \%$, dan $100 \%$, membuat suspensi kuman menjadi $10^{-1}, 10^{-2}$, $10^{-3}$ dan $10^{-4}$, pembuatan dan sterilisasi media Natrium Agar (NA).
3) Tahap pegumpulan data: a) Kertas cakram steril direndam dalam ekstrak daun kersen untuk konsentrasi $0 \%, 25 \%, 50 \%, 75 \%$ dan $100 \%$ selama 30 menit, b) Bakteri Salmonella typhi diinkubasikan pada media Nutrien Agar (NA) dengan cara ambil 0,1 ml biakan bakteri Salmonella typhi yang telah diencerkan dan dimasukkan ke dalam petridish dengan teknik pour plate lalu tuangkan Nutrien Agar (NA) dan biarkan sampai membeku setelah itu kertas cakram yang telah direndam dalam ekstrak diletakan pada permukaan media Nutrien Agar (NA) yang sudah diinokulasi bakteri Salmonella typhi, kemudian diinkubasi selama 24 jam pada suhu $37^{\circ} \mathrm{C}$, c) Zona bening yang terbentuk di sekitar kertas cakram, diukur diameternya dengan menggunakan jangka sorong. Dari prosedur yang diuraikan di atas maka data yang menggambarkan tentang ada tidaknya kemampuan ekstrak daun kersen sebagai anti bakteri berupa luas zona hambat. 4) Tahap analisis data: untuk membuktikan ada tidaknya kemampuan anti bakteri ekstrak daun kersen maka dianalisis yng digunakan yaitu analisis varians (ANAVA) satu arah. Ringkasan Rumus ANAVA sebagai berikut

Tabel 1. Analisis Varians (ANAVA) Kemampuan Anti Bakteri Ekstrak Daun Kersen

\begin{tabular}{ccccc}
\hline Sumber Variasi & $d f$ & $S S$ & $M S$ & F-HITUNG \\
\hline Antar Perlakuan & $k-1$ & $S S_{p}$ & $\frac{S S_{p}}{k-1}$ & $\frac{M S_{p}}{M S_{E}}$ \\
$\begin{array}{ccc}\text { Dalam Perlakuan } \\
\text { (error) }\end{array}$ & $(n-1) \cdot(k-1)$ & $S S_{E}=S S_{T}-S S_{p}$ & $\frac{S S_{E}}{(n-1)-(k-1)}$ & \\
\hline Total & $n-1$ & $S S_{T}$ & & \\
\hline
\end{tabular}

Apabila F hitung $>$ F Tabel maka dilanjutkan dengan uji lanjutan beda nyata terkecil (BNT) dengan taraf signifikan 1\%. Rumus

$$
\mathrm{BNT} \alpha=\mathrm{t} \cdot \alpha \sqrt{\frac{2 \mathrm{KTG}}{\mathrm{r}}}
$$

BNT sebagai berikut: 
HASIL DAN PEMBAHASAN

1. Data hasil Penilaian Keterampilan

Proses

Pembentukan kemampuan pada aspek keterampilan proses dalam menerapkan langkah-langkah metode inkuiri bebas termodifikasi pada setiap mahasiswa diuraikan pada bagian berikut ini: a) Merumuskan masalah $100 \%$, b) merumuskan hipotesis $100 \%$, c)Tahap Pengenalan alat 95\%, d)Tahap persiapan sampel $90 \%$, e)Tahap persiapan bahan uji $87,35 \%$, f) Tahap persiapan bakteri uji $84,23 \%$, g) Tahap pengambilan data $88,65 \%$ dan h)pengujian hipotesis (analisis data) 86, $06 \%$

\section{Hasil uji anti bakteri ekstrak daun kersen}

Berdasarkan uji aktivitas anti bakteri ekstrak daun kersen terhadap pertumbuhan bakteri Salmonella thypi secara in vitro selama 24 jam menunjukkan bahwa adanya zona hambat yang terbentuk disekitar kertas cakram. Hasil lengkap pengukuran zona hambat dapat dilihat pada tabel 3.1 berikut.

Tabel 2. Hasil Pengukuran Zona Hambat Bakteri Salmonella thypi

\begin{tabular}{ccccccc}
\hline No & Konsentrasi & \multicolumn{3}{c}{ Ulangan } & Jumlah (mm) & $\begin{array}{c}\text { Rata-Rata } \\
(\mathbf{m m})\end{array}$ \\
\hline 1 & $0 \%$ & 0 & 0 & 0 & 0 & 0 \\
2 & $25 \%$ & 13.1 & 10.5 & 15.9 & 39.5 & 13.16666667 \\
3 & $50 \%$ & 12.1 & 9.8 & 14.2 & 36.1 & 12.03333333 \\
4 & $75 \%$ & 13.3 & 13.1 & 13.1 & 39.5 & 13.16666667 \\
5 & $100 \%$ & 13.7 & 11.8 & 13.9 & 39.4 & 13.13333333 \\
\hline
\end{tabular}

Tabel 2 menunjukkan adanya zona hambat pada pertumbuhan bakteri Salmonella thypi pada ke 4 konsentrasi ekstrak yaitu 25\%, $50 \%, 75 \%, 100 \%$. Hal ini (adanya zona hambat) menunjukkan bahwa ekstrak daun kersen memiliki kemampuan sebagai anti bakteri. Apabila zat antibakteri bersifat menghambat atau membunuh bakteri tersebut maka pertumbuhan bakteri akan terhenti di daerah sekitar kertas cakram yang ditandai dengan terbentuknya zona bening di sekitar cakram. Luas zona hambat sebagaimana di uraikan pada Tabel 2 dan dapat dilihat pada gambar 1 berikut. 

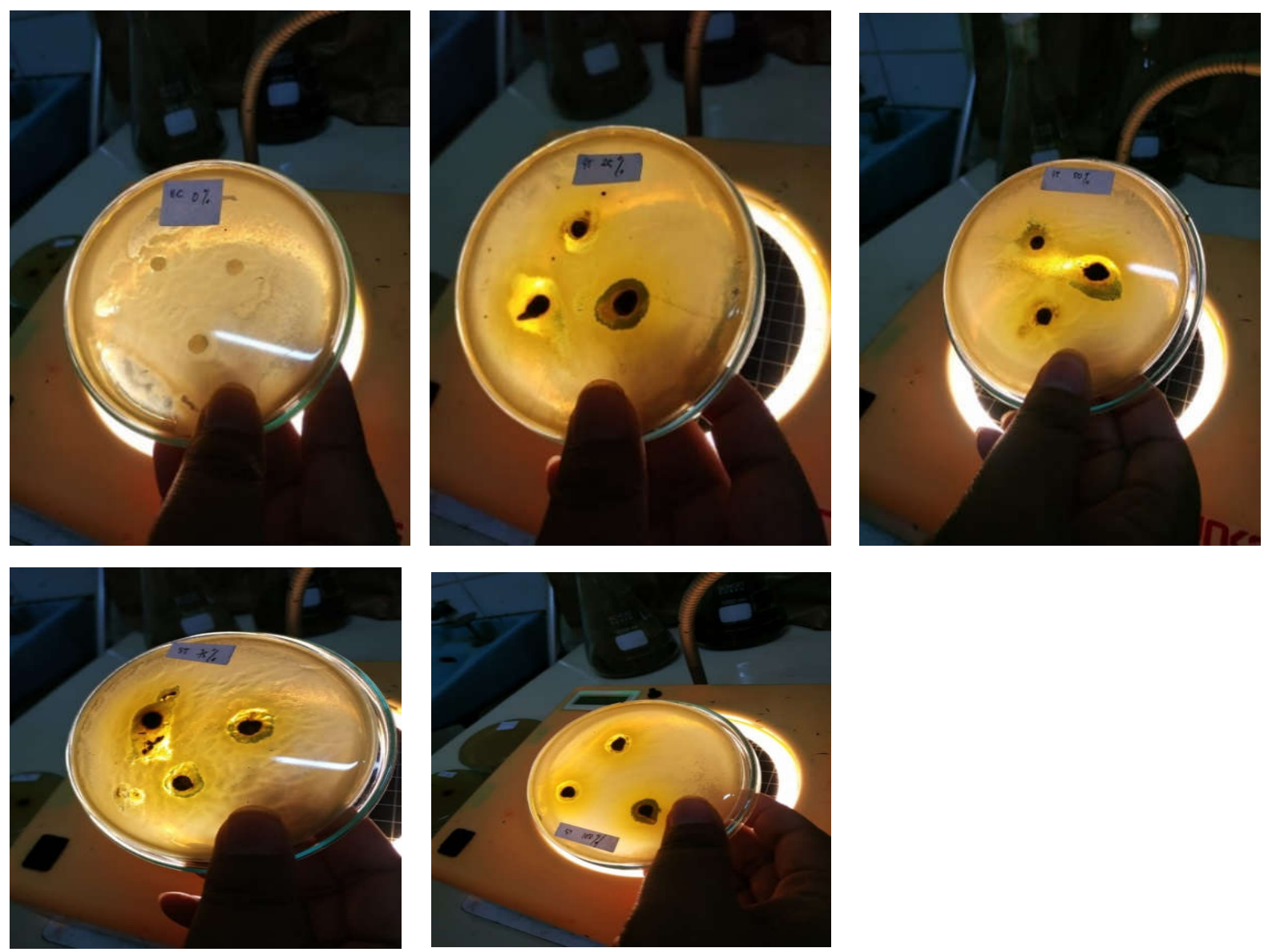

Gambar 1. Penampakan Luas Zona Hambat Pertumbuhan Bakteri

Gambar 1 memperlihatkan hasil pengukuran dari aktivitas antibakteri jelas memperlihatkan adanya zona hambat (zona bening) yang terbentuk setelah diinkubasi selama 24 jam dengan rerata yang berbeda pada setiap perlakuan ekstrak daun kersen. Pada kontrol negative $(0 \%)$ tidak terjadi zona hambat pada kertas cakram, Pada konsentrasi $(25 \%)$ terjadi zona hambat mencapai rata-rata $13.16 \mathrm{~mm}$ pada daerah sekitar kertas cakram, Pada konsentrasi (50\%) terjadi zona hambat mencapai rata-rata $12.02 \mathrm{~mm}$ pada daerah sekitar kertas cakram, Pada konsentrasi (75\%) terjadi zona hambat mencapai rat-rata $13.16 \mathrm{~mm}$ pada daerah sekitar kertas cakram, Pada konsentrasi (100\%) terjadi zona hambat mencapai rat-rata $13.13 \mathrm{~mm}$ pada daerah sekitar kertas cakram.

Untuk mengolah data yang sudah diperoleh dalam mengkur zona hambat pada tabel 2 dianalisis dengan teknik perhitungan yang disebut Analisis Varian (ANAVA). Teknik perhitungan dilakukan untuk mengetahui ada tidaknya kemampuan ekstrak daun kersen sebagai anti bakteri terhadap pertumbuhan bakteri Salmonella thypi dengan tingkat signifikan $(0,01)$.

a. Menentukan Derajat bebas perlauan (DB)

1. Derajat Bebas Total $=(\mathrm{t}$. r $)-1=($ 4.3) $-1=12-1=11$

2. Derajat Bebas Perlakuan $\quad=\mathrm{t}-1=$ 4-1 = 3

3. Derajat Bebas Galat $=\mathrm{DBT}-\mathrm{DBP}=$ $11-3=8$

b. Menetukan Faktor Koreksi (FK)

$$
\begin{aligned}
& F K=\frac{T_{i} j^{2}}{r \cdot t}=\frac{(154.5)^{2}}{4.3}=\frac{2387025}{12}= \\
& 1989,1875
\end{aligned}
$$

1. Menentukan Jumlah Kuadrat (JK)

a) Jumlah Kuadrat Total (JKT) 


$$
\begin{aligned}
& J K T=\left(P_{1}\right)^{2}+\left(P_{2}\right)^{2}+\cdots\left(P_{n}\right)^{2}- \\
& F=0^{2}+0^{2}+0^{2}+13.1^{2}+ \\
& 10.5^{2}+15.9^{2}+12.1^{2}+9.8^{2}+ \\
& 14.2^{2}+13.3^{2}+13.1^{2}+13.1^{2}+ \\
& 13.7^{2}+11.8^{2}+13.9^{2}- \\
& (1989,1875)=201901- \\
& (1989,1875)=2017.9118
\end{aligned}
$$

b) Jumlah Kuadrat Perlakuan (JKP)

$$
J K P
$$

$$
\begin{aligned}
& =\frac{(T A)^{2}+(T B)^{2}+(T C)^{2}+\cdots+(T n)^{2}}{r} \\
& -F K \\
& =\frac{(39.5)^{2}+(36.1)^{2}+(39.5)^{2}+(39.4)^{2}}{3} \\
& -(2017.9118) \quad 3 \\
& =\frac{1560.25+1303.21+1560.25+1552.36}{3} \\
& -(2017.9118) \\
& =\frac{597.607}{3}-2017.9118 \text { JKP } \\
& =199.202-2017.9118=197.184 \\
& \text { c) Jumlah Kuadrat Galat }(\mathrm{JKG}) \\
& \quad \text { JKG = JKT }- \text { JKP }
\end{aligned}
$$

\begin{tabular}{|c|c|c|c|c|c|}
\hline & & 2017.9118 & & & \\
\hline Perlakuan & 3 & & 65.728 & 8.000 & 7,59 \\
\hline Galat & 8 & 101,041 & 8.216 & & \\
\hline Total & 11 & 20,177 & & & \\
\hline
\end{tabular}

$\mathrm{JKG}=$

$29.8225-197.184=101,041$

2. Menghitung Kuadrat Tengah (KT)

a) Kuadrat Tengah Perlakuan (KTP)

$$
K T P=\frac{J K P}{D B P}=\frac{197.184}{3}=65.728
$$

b) Kuadrat Tengah Galat (KTG)

$$
K T G=\frac{J K G}{D B G}=\frac{65.728}{8}=8.216
$$

3. Menentukan Fhitung

$$
F_{\text {hitung }}=\frac{K T P}{K T G}=\frac{65.728}{8.216}=8.000
$$

4. $F_{\text {tabel }}(0.05)$ dan $(0.01)$

Nilai $F_{\text {tabel }}(0.01)=(0.01 . D B P$,

$$
\mathrm{DBG})=\mathbf{7 , 5 9}
$$

Tabel 3. Hasil Analisis Varians (ANAVA)

$\begin{array}{llllll}\begin{array}{l}\text { Sumber } \\ \text { Variasi }\end{array} & \text { DB } & \text { JK } & \text { KT } & \text { F hitung } & \text { F tabel }\end{array}$

0.01

Pada Tabel $3 \mathrm{~F}$ hitung $>$ F Tabel, menyatakan adanya pengaruh nyata pada setiap konsentrasi ekstrak daun kersen maka dilanjutkan uji Uji Beda Nyata Terkecil (BNT) taraf Sig. $1 \%$

BNT $\alpha=\quad t . \alpha \cdot \sqrt{\frac{2 K T G}{r}}$

Dik : $\mathrm{KTG}=8.216 \alpha=0,01 \mathrm{DBG}=8$ t. $0,01,8=2,896$

$$
\begin{aligned}
\text { BNT } \alpha= & 2,896 \sqrt{\frac{2 \cdot 8 \cdot 216}{3}} 2,896 \sqrt{\frac{16.432}{3}} \quad 2,896 \sqrt{5.477} 2,896 \text {. 2,333 } \\
& =6.756
\end{aligned}
$$


Tabel 4. Hasil Uji Lanjut Beda Nyata Terkecil (BNT) Pengaruh Ekstrak Pada Taraf Signifikan 0,01

\begin{tabular}{|c|c|c|c|c|c|c|c|c|}
\hline Konsentrasi & Perlakuan & $\begin{array}{c}\text { Rata- } \\
\text { rata }\end{array}$ & $\begin{array}{c}0 \\
0,00\end{array}$ & $\begin{array}{c}1 \\
13.16\end{array}$ & $\begin{array}{c}2 \\
12.02\end{array}$ & $\begin{array}{c}3 \\
13.16\end{array}$ & $\begin{array}{c}4 \\
13.13\end{array}$ & $\begin{array}{c}\text { BNT 1\% } \\
(7,113)\end{array}$ \\
\hline $0 \%$ & 0 & 0 & 0 tn & & & & & $\mathbf{A}$ \\
\hline $25 \%$ & 1 & 13.16 & $13.16^{*}$ & 0 tn & & & & $\mathbf{B}=\mathbf{C}$ \\
\hline $50 \%$ & 2 & 12.02 & $12.02 *$ & $24.04 \mathrm{tn}$ & 0 tn & & & $C=D$ \\
\hline $75 \%$ & 3 & 13.16 & $13.16^{*}$ & $10,08^{*}$ & $26.32 \mathrm{tn}$ & 0 tn & & $\mathbf{D}=\mathbf{E}$ \\
\hline $100 \%$ & 4 & 13.13 & $13.13^{*}$ & $26.26^{*}$ & $8,45^{*}$ & $2,61 \mathrm{tn}$ & 0 tn & $\mathbf{E}$ \\
\hline
\end{tabular}

\section{PEMBAHASAN}

\section{Kemampuan dalam Keterampilan Proses}

Dalam proses pembelajaran dengan menggunakan metode-metode saintifik termasuk inkuari capaian pembelajaran yang diharapkan tidak hanya menekankan pada aspek kognitif saja, tetapi terutama ditekankan pula pada aspek psikomotorik. Keterampilan proses yang merupakan pengejawantahan aspek psikomotorik mendorong insan Indonesia untuk menjadi problem solver yang berkompetensi menyelesaikan permasalahan-permasalah diri dan sekitarnya oleh dirinya sendiri. Dan hal ini akan membentuk rasa percaya diri dalam menemukan solusi-solusi baru terhadap permasalahan yang dihadapinya dan tidak mengadopsi solusi yang ditawarkan oleh bangsa lain.

Dalam penelitian ini tujuan sebagaimana diuraikan di atas menjadi target pembentukan kompetensi pada mahasiswa keguruan dari program studi Pendidikan Biologi Universitas Katolik Widya Mandira Kupang.

Setelah melalui tahapan persiapan sampai pada implementasinya di dalam rangkaian pelaksanaan pembelaaran dengan metode inkuari bebas termodifikasi di dapatlah hasil pembentukan keterampilan proses mahasiswa sebagaimana diuraikan di berikut ini: a) Merumuskan masalah 100 $\%$, b) merumuskan hipotesis 100\%, c)Tahap Pengenalan alat 95\%, d)Tahap persiapan sampel 90\%, e)Tahap persiapan bahan uji $87,35 \%$, f) Tahap persiapan bakteri uji 84,23\%, g) Tahap pengambilan data $88,65 \%$ dan h)pengujian hipotesis (analisis data) $86,06 \%$

Berdasarkan data keterampilan proses sebagaimana di uraikan di atas terlihat bahwa rata-rata kemampuan keterampilan proses mahasiswa dalam menerapkan tahap-tahap inkuari bebas termodifikasi berada di atas $80 \%$. Hal ini terjadi karena menurut Hanafiah, 2019 metode pembelaaran inkuri dari jenis apapun baik inkuari terbimbing, inkuari bebas maupun kombinasi kedua inkuari terbimbing dan bebas, apabila para peserta didik dipersipakan secara matang pada tahap orientasi dengan jumlah rombongan yang kecil maka peserta didik akan: 1) Dapat memiliki keterampilan dalam proses kognitif, 2) memperoleh pengetahuan secara individual yang dapat di mengerti dan terserap dalam pikirannya, 3) dapat 
membangkitkan motivasi dan gairah belajar peserta didik yang lebih tinggi lagi, 4) memperkuat dan menambah kepercayaan pada diri sendiri karena adanya proses menemukan sendiri, tanpa ada intervensi guru yang terlalu jauh atau yang terlalu tinggi.

\section{Hasil uji anti bakteri ekstrak daun kersen}

Berdasarkan hasil analisis varian satu arah hasil dari penelitian ini menunjukkan bahwa ekstrak daun kersen berkamampuan sebagai anti bakteri yang ditandai dengan $\mathrm{F}$ hitung $=8,00>\mathrm{F}$ Tabel $=7,59$. Hal ini terjadi karena adanya kandungan zat aktif pada daun kersen yang mampu menghambat pertumbuhan bakteri Salmonella thypi yaitu Flavonoid, Tanin, Triterpenoid, Saponin, dan Polifenol. Falfonoid sendiri merupakan senyawa metabolit yang sering ditemukan pada tumbuhan. Salah satu peran flafonoid bagi tumbuhan adalah sebagai anti mikroba dan anti virus sehingga tubuhan yang mengandung flafonoid banyak dipakai dalam

\section{KESIMPULAN}

Berdasarkan hasil analisis data disimpulkan bahwa motivasi dan kepercayan diri yang kuat dari mahasiswa pelaksana metode pembelajaran inkuari bebas termodifikasi di dukung dengan orientasi pemahaman dan keterampilan mengenai konsep inkuari bebas termodifikasi dan langkah-langkah penerapannya yang terlaksana dengan baik maka penerapannya di dalam penelitian ini di peroleh nilai keterampilan proses rata-rata di atas $80 \%$.

\section{DAFTAR PUSTAKA}

Depdiknas. 2005. Peraturan Pemerintah Republik Indonesia No.19 Tahun. 2005 Tentang Standar Nasional pengobatan tradisional (Robinson, 1998). Mekanisme kerja flavonoid sebagai antibakteri adalah membentuk senyawa kompleks dengan protein ekstrakseluler dan terlarut seingga dapat merusak membrane sel bakteri dan diikuti dengan keluarnya senyawa intraseluler (IndoBIC,N2005). Pada umumnya senyawa flafonoid dapat menghambat bakteri gram positif dan negatif (Cowan, 1999 dalam Melky, 2011).

Berdasarkan hasil perhitungan atau uji lanjutan beda Nyata terkecil (BNT) terlihat bahwa antar perlakuan yang satu dengan yang lain (dengan konsentrasi ekstrak yang berbeda-beda) memiliki kemampuan anti bakteri yang berbeda-beda pula. Hal ini terjadi karena menurut Cowan, 1999 dalam Melky, 2011, bahwa bahan aktif yang berpengaruh terhadap bakteri baik gram negatif maupun positif sangat tergantung pada kandungannya di dalam ekstrak, dimana semakin konsentrasi bahan aktif semakin tinggi pula kemampuan anti bakterinya

Hal ini menentukan kualitas pelaksanaan penelitian.

Dengan kemampuan keterampilan proses yang sangat baik sebagaimana disebutkan di atas diperoleh hasil penelitian mengenai kemampuan anti bakteri ekstrak daun kersen terhadap Salmonella tiphy sebagai berikut: bahwa ekstrak daun kersen memiliki kemampuan anti bakteri terhadap Salmonella tiphy dimana pada konsentrasi yang berbeda menunjukkan kemampuan anti bakteri yang berbeda pula.

Pendidikan, Jakarta: Deprtemen Pendidikan Nasional

Depkes RI. 2007. Profil Kesehatan 2007. Departemen Kesehtan RI 
Departemen Kesehatan RI. Undang-Undang Republik Indonesia Nomor 36 Tahun 2009 Tentang Kesehatan. Jakarta: Kementrian Kesehatan RI: 2009

Harbone, J.B.1987. Metode Fitokimia Penuntun Cara Modern Menganalisis Tumbuan.terbitan kedua.Diterjemahkan oleh Kokasih Padmawinata dan I.Soediso.Bandung: ITB Press.

Kementrian Kesehatan RI. 2007. Kebijakan Obat Tradisional Nasional.Jakarta: Depertemen Kesehan RI.

Pelczar.M.J. Dan Chan, R. C. S. 2005. Dasar-Dasar Mikrobiologi 1.UI : Press Jakarta

Sukandar E. 2006. Gagal Ginjal dan Panduan Terapi Dialisis. Bandung: Pusat Informasi Ilmiah Bagian Ilmu
Penyakit Dalam Fakultas Kedokteran Universitas Padjajaran/RS Dr. Hasan Sadikin Bandung

Soeryoko, Hery. 2011. Kiat Pintar Memproduksi Cair dengan Pengurai Buatan Sendiri. Yogyakarta: Lily Publisher

Sudirman,Taufik Azhari. 2014. Deteksi Senyawa Antimikroba.Universitas Makassar:Gadja Mada Universitas Press.

Soedarto.2015. Mikrobiologi Kedokteran. Jakarta: CV. Sagung Seto.

Seran, L, Herak, R. 2020. Uji Aktifitas Anti Bakteri Ekstrak Rimpang Jahe Terhadap E.Colli Secara In Vitro Melalui Model PBL. Bio Educatio. Vol.5, No 1 hal. 48-56 